\title{
Preparation and visible light catalytic activity of three-dimensional ordered macroporous $\mathrm{CdS} / \mathrm{TiO}_{2}$ films
}

\author{
CHEN Xiaofang, ZHANG Jia, HUO Yuning *, LI Hexing\# \\ Department of Chemistry, Shanghai Normal University, Shanghai 200234, China
}

\section{A R T I C L E I N F O}

Article history:

Received 6 January 2013

Accepted 15 February 2013

Published 20 May 2013

\section{Keywords:}

$\mathrm{CdS} / \mathrm{TiO}_{2}$ film

Three-dimensional ordered

macroporous structure

Visible light

Photocatalysis

\begin{abstract}
A B S T R A C T
A three-dimensional ordered macroporous $\mathrm{CdS} / \mathrm{TiO}_{2}$ film was prepared by the sol-gel method with a colloidal crystal template and $\mathrm{S}^{2-}$ ion exchange, and it exhibited high visible light photocatalytic activity for the aqueous degradation of rhodamine B and 4-chlorophenol. The modification with CdS gave visible light absorption by photosensitization and better separation of photo-induced electrons and holes. The ordered macroporous structure gave higher light utilization and faster reactant transport.
\end{abstract}

(C) 2013, Dalian Institute of Chemical Physics, Chinese Academy of Sciences. Published by Elsevier B.V. All rights reserved.

\section{Introduction}

Organic pollutants are the main source of global pollution, especially water pollution $[1,2]$. The removal of organic pollutants by photocatalytic degradation technology has the advantages of environmental friendliness, mild reaction conditions, low energy consumption, and low cost $[3,4]$. Although the commonly used $\mathrm{TiO}_{2}$ photocatalyst is stable, non-toxic, and cheap, it can be only excited by UV light and has low utilization of solar light because of the large band gap. At the same time, its quantum efficiency is very low $[5,6]$. $\mathrm{TiO}_{2}$ can be modified to give a photocatalytic reaction under visible light irradiation [7]. The $\mathrm{CdS} / \mathrm{TiO}_{2}$ visible light phtocatalyst has attracted much attention because the photosensitization by $\mathrm{CdS}$ gives a narrow band gap (2.4 eV) [8]. Previous research has mainly focused on the $\mathrm{CdS} / \mathrm{TiO}_{2}$ powder $[9,10]$, but this is difficult to separate from the reaction in the aqueous solution.
A photocatalytic film reactor can allow the continuous treatment of aqueous organic pollutants because there is no need for catalyst separation. At present, it is still very difficult to prepare a $\mathrm{CdS} / \mathrm{TiO}_{2}$ film with a good distribution of $\mathrm{CdS}$ and strong bonding of $\mathrm{CdS}$ to $\mathrm{TiO}_{2}$. Furthermore, the light utilization of most photocatalytic films is low, and mass transfer limitation is severe. A three-dimensional ordered and macroporous structure has been confirmed as effective for increasing the surface area, enhancement of reactant transfer, and increased light absorbance, and it has received much attention for applications in pollutant control and solar energy utilization $[11,12]$. Here, a three-dimensional ordered macroporous $\mathrm{CdS} / \mathrm{TiO}_{2}$ film was prepared by the sol gel method with a colloidal crystal template and $\mathrm{S}^{2-}$ ion exchange. The $\mathrm{CdS} / \mathrm{TiO}_{2}$ film exhibited improved light harvesting and visible light photocatalytic activity.

\footnotetext{
*Corresponding author. Tel: +86-21-64322272; Fax: +86-21-64322272; E-mail: Huoyuning@shnu.edu.cn \# Corresponding author. Tel: +86-21-64322272; Fax: +86-21-64322272; E-mail: Hexing-li@shnu.edu.cn This work was supported by National Natural Science Foundation of China (20937003, 21261140333, 21237003, and 21207091) and Shanghai Government (11JC1409000, 12230706000, and 12YZ091). DOI: 10.1016/S1872-2067(12)60560-9 | http://www.sciencedirect.com/science/journal/18722067 | Chin. J. Catal., Vol. 34, No. 5, May 2013
} 


\section{Experimental}

\subsection{Preparation of the $\mathrm{CdS} / \mathrm{TiO}_{2}$ membrane}

\subsubsection{Fabrication of the colloidal crystal template}

The mono-dispersed polystyrene microspheres used as the colloidal crystal template were prepared by emulsifier-free batch emulsion polymerization [13]. Styrene (21 ml), acroleic acid $(0.95 \mathrm{ml})$, and methyl methacrylate $(1.1 \mathrm{ml})$ were dissolved in $6.3 \mathrm{mmol}$ ammonium bicarbonate buffer solution (0.50 g ammonium bicarbonate added in $100 \mathrm{ml}$ distilled water) and kept at $70{ }^{\circ} \mathrm{C}$ for $0.5 \mathrm{~h}$. Then, $2.3 \mathrm{mmol}$ ammonium persulfate was added and the solution was heated to $80^{\circ} \mathrm{C}$ with stirring for $10 \mathrm{~h}$ to get a suspension of mono-dispersed polystyrene microspheres of poly[styrene-methyl methacrylate-acroleic acid] (denoted P(ST-MMA-AA).

\subsubsection{Fabrication of the colloidal crystal film}

The glass substrate with the size $2.5 \mathrm{~cm} \times 2.0 \mathrm{~cm}$ was first treated with $1.0 \mathrm{~mol} / \mathrm{L} \mathrm{NaOH}$ solution for $2 \mathrm{~h}$, ultrasonically cleaned with acetone, ethanol, and water three times, respectively, and then dried in air. The glass substrate was immersed vertically in the aqueous suspension of PS colloidal crystal of $0.25 \mathrm{wt} \%$ and kept at $60{ }^{\circ} \mathrm{C}$ for $24 \mathrm{~h}$ to get the colloidal crystal film on the substrate by the evaporation effect.

\subsubsection{Fabrication of the $3 \mathrm{D} \mathrm{OM} \mathrm{CdS} / \mathrm{TiO}_{2}$ film}

$\mathrm{TiCl}_{4}(1.0 \mathrm{ml})$ was added dropwise into $20 \mathrm{ml}$ ethanol solution with stirring for $5 \mathrm{~min}$. The desired amount of $\mathrm{Cd}\left(\mathrm{NO}_{3}\right)_{2}$ was added with stirring and completely dissolved, and $3.0 \mathrm{ml}$ tetrabutyl titanate was then added, followed by stirring for $2 \mathrm{~h}$ to get the $\mathrm{CdS} / \mathrm{TiO}_{2}$ precursor. Then, $0.10 \mathrm{ml}$ precursor was dropped into the voids of the PS colloidal crystal template at a $15^{\circ}$ inclination angle of glass substrate and dried at ambient temperature. The sample was calcined at $400{ }^{\circ} \mathrm{C}$ for $6 \mathrm{~h}$ by heating at $2{ }^{\circ} \mathrm{C} / \mathrm{min}$. After it was cooled, the sample was immerged into $0.20 \mathrm{~mol} / \mathrm{L} \mathrm{Na} 2 \mathrm{~S}$ solution for $12 \mathrm{~h}$ for the ion exchange, followed by washing in deionized water and drying. The sample obtained was denoted $x \mathrm{CdS} / \mathrm{TiO}_{2}$, in which $x$ was the $\mathrm{Cd} / \mathrm{Ti}$ molar ratio, with values of $0.00 \%, 0.25 \%, 0.50 \%$, $0.75 \%$, and $1.0 \%$, respectively. The macroporous structure was not obtained with higher Cd/Ti molar ratios.

For comparison, two film samples, $\mathrm{TiO}_{2}(\mathrm{C})$ and $1.0 \% \mathrm{CdS} /$ $\mathrm{TiO}_{2}(\mathrm{C})$, were prepared by the dip-coating process with the same sol gel precursor in the absence of the PS colloidal crystal template. The $1.0 \% \mathrm{CdO} / \mathrm{TiO}_{2}$ film was synthesized without the $\mathrm{Na}_{2} \mathrm{~S}$ ion exchange.

\subsection{Characterization}

The photocatalyst structure was determined from X-ray diffraction (XRD) patterns recorded on a Rigaku Dmax-3C apparatus with $\mathrm{Cu} K_{\alpha}$ radiation $\left(\lambda=0.154 \mathrm{~nm}, 4^{\circ} / \mathrm{min}\right)$. Surface morphologies were observed by field emission scanning elec- tron microscopy (FESEM, HITACHI S-4800) and high resolution transmission electronic microscopy (HRTEM, JEM-2010). $\mathrm{N}_{2}$ adsorption-desorption isotherms were measured on a Quantachrome NOVA 4000e at $-196{ }^{\circ} \mathrm{C}$. The Brunauer-Emmett-Teller (BET) method was used to calculate the specific surface area $\left(A_{\mathrm{BET}}\right)$, and the pore distribution was obtained from the adsorption branch. The transmittance spectra were obtained on a Shimadzu UV-2450 UV-Vis spectrophotometer in the range of 200 to $800 \mathrm{~nm}$ using $\mathrm{BaSO}_{4}$ as the reflectance standard. X-ray photoelectron spectroscopy (XPS, Versa Probe PHI 5000) was employed to determine surface electronic states (Al $K_{\alpha}$ radiation, $1486.6 \mathrm{eV}$ ). The shift of the binding energy due to surface charging was corrected using the $\mathrm{C} 1 \mathrm{~s}$ level at 284.8 $\mathrm{eV}$ as an internal standard. Photoluminescence spectra (PLS) were collected on a Varian Cary-Eclipse 500 (65 W Xe lamp, $600 \mathrm{~nm} / \mathrm{min}$ ).

\subsection{Photocatalytic test}

A glass sheet $(2.5 \mathrm{~cm} \times 2.5 \mathrm{~cm})$ coated with the $\mathrm{CdS} / \mathrm{TiO}_{2}$ catalyst was placed in $5.0 \mathrm{ml} 10 \mathrm{mg} / \mathrm{L}$ rhodamine B (RhB) solution or $5.0 \mathrm{ml} 15 \mathrm{mg} / \mathrm{L}$ 4-chlorophenol (4-CP) solution for the evaluation of photocatalytic activity. The photocatalytic film was illuminated by a $500 \mathrm{~W}$ Xe lamp. UV light with wavelengths less than $420 \mathrm{~nm}$ were removed by a glass filter. The reaction temperature was $30{ }^{\circ} \mathrm{C}$. Adsorption-desorption equilibrium was achieved by adsorption for $30 \mathrm{~min}$ in the dark before the photocatalytic reaction. After irradiation for $100 \mathrm{~min}$, the concentration of $\mathrm{RhB}$ or 4-CP was determined by measuring the light absorbance using the UV-Vis spectrophotometer using the characteristic peak of RhB (554 nm) or 4-CP (224 nm), and the degradation rate was calculated.

\section{Results and discussion}

\subsection{Characterization results}

FESEM images (Fig. 1) of the $1.0 \% \mathrm{CdO} / \mathrm{TiO}_{2}$ and $1.0 \% \mathrm{CdS} / \mathrm{TiO}_{2}$ films reveal that an ordered macroporous structure was present on a large scale in the $1.0 \% \mathrm{CdO} / \mathrm{TiO}_{2}$

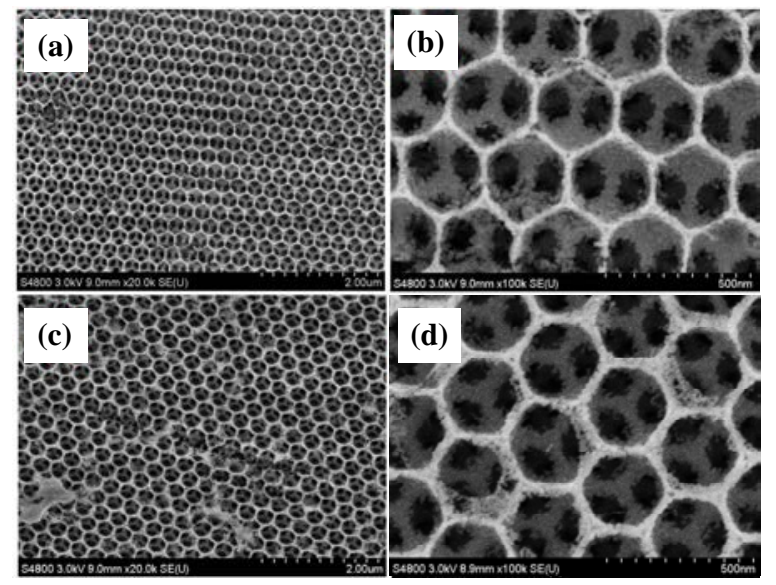

Fig. 1. FESEM images of different films. (a) $1.0 \% \mathrm{CdO} / \mathrm{TiO}_{2}$; (b) Enlarged view of (a); (c) $1.0 \% \mathrm{CdS} / \mathrm{TiO}_{2}$; (d) Enlarged view of (c). 


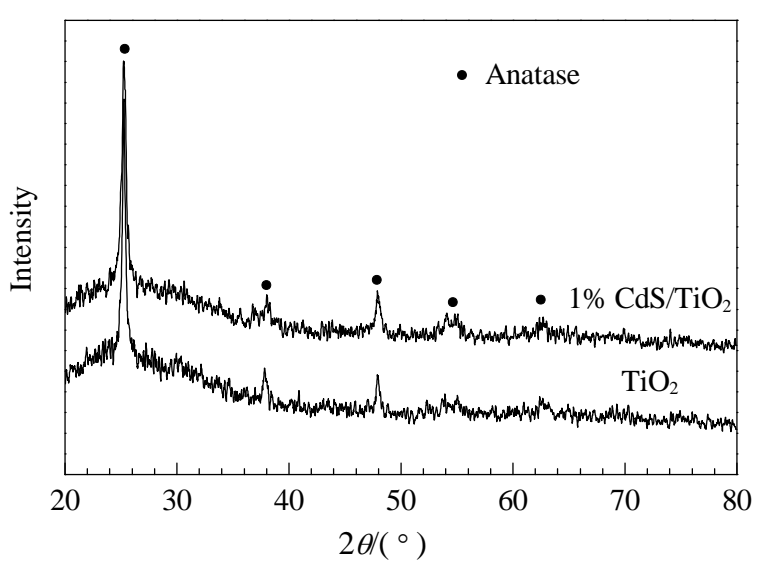

Fig. 2. XRD patterns of $\mathrm{TiO}_{2}$ and the $1 \% \mathrm{CdS} / \mathrm{TiO}_{2}$ film.

sample and that this was maintained well in the $1.0 \% \mathrm{CdS} / \mathrm{TiO}_{2}$ film after the ion exchange. The pore diameter was $300 \mathrm{~nm}$ and the thickness of the pore wall was $40 \mathrm{~nm}$. This indicates that an ordered macroporous $\mathrm{CdS} / \mathrm{TiO}_{2}$ film can be successfully prepared by the sol gel method with a colloidal crystal template and $\mathrm{S}^{2-}$ ion exchange. From the XRD patterns in Fig. 2, the $1.0 \% \mathrm{CdS} / \mathrm{TiO}_{2}$ film has the same diffraction peaks as the $\mathrm{TiO}_{2}$ film composed of anatase $\mathrm{TiO}_{2}$ (JCPDS 21-1272). No obvious peak for CdS was observed due to the high dispersion and low concentration of CdS.

In the HRTEM image of the $1.0 \% \mathrm{CdS} / \mathrm{TiO}_{2}$ film in Fig. 3 , two crystal lattice fringes with the inter-planar spaces for the $\mathrm{TiO}_{2}(101)$ plane $(0.35 \mathrm{~nm})$ and $\mathrm{CdS}(002)$ plane $(0.34 \mathrm{~nm})$, re-

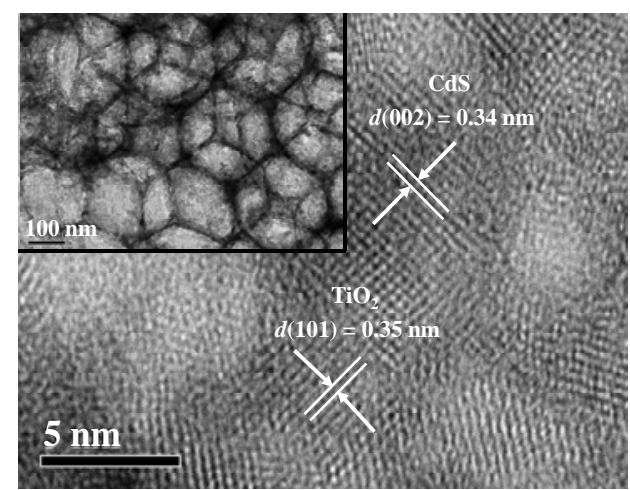

Fig. 3. HRTEM and inset TEM images of the $1.0 \% \mathrm{CdS} / \mathrm{TiO}_{2}$ film.

spectively, were observed, which was in accordance with a previous report [14]. It was further confirmed that CdS was uniformly distributed in the $\mathrm{TiO}_{2}$ ordered macroporous structure with high crystallization. The inset TEM image also shows the structure of ordered macropores, corroborating the above results.

Figure 4 shows the XPS spectra of the $1.0 \% \mathrm{CdS} / \mathrm{TiO}_{2}$ film, which showed that the peak positions of Ti $2 p, 01 s$, and $\mathrm{Cd} 3 d$ were the same as those of pure $\mathrm{TiO}_{2}$ and $\mathrm{CdS}[15,16]$. It was demonstrated that the $\mathrm{CdS}$ was present in combination with $\mathrm{TiO}_{2}$ in a composite because the radius of $\mathrm{Cd}^{2+}(97 \mathrm{pm})$ was larger than that of $\mathrm{Ti}^{4+}(61 \mathrm{pm})$, which makes it difficult to enter the crystal lattice of $\mathrm{TiO}_{2}$ to give ion doping.

The $\mathrm{N}_{2}$ adsorption-desorption isotherm and pore size distribution of the $1.0 \% \mathrm{CdS} / \mathrm{TiO}_{2}$ sample are presented in Fig. 5.
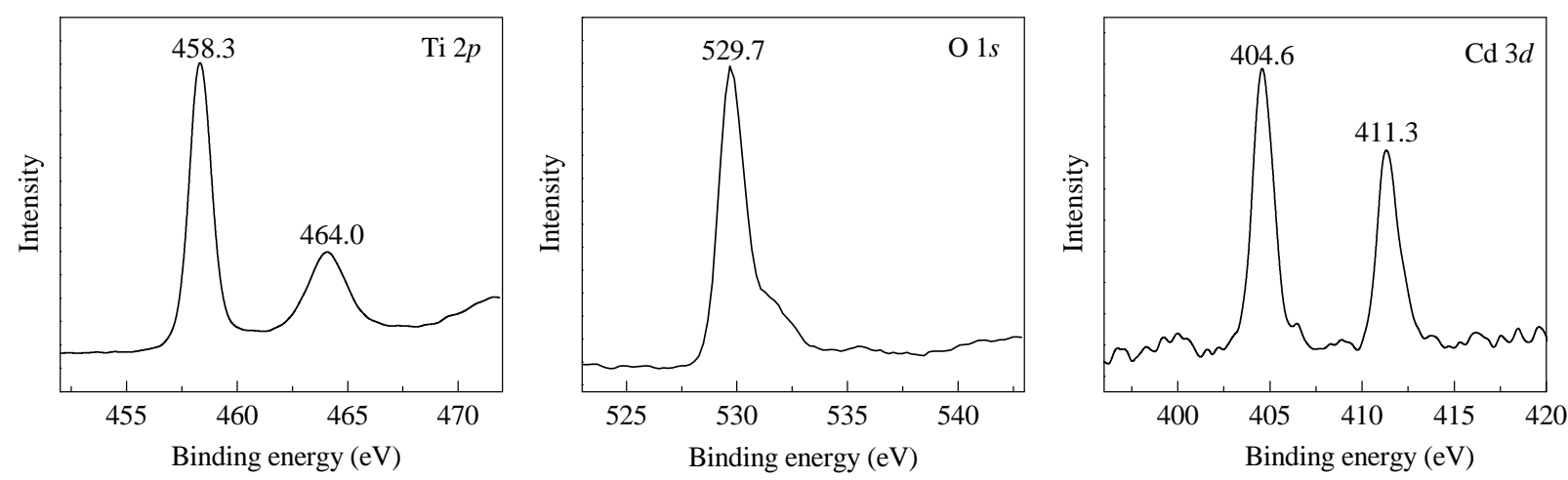

Fig. 4. XPS spectra of the $1.0 \% \mathrm{CdS} / \mathrm{TiO}_{2}$ film.
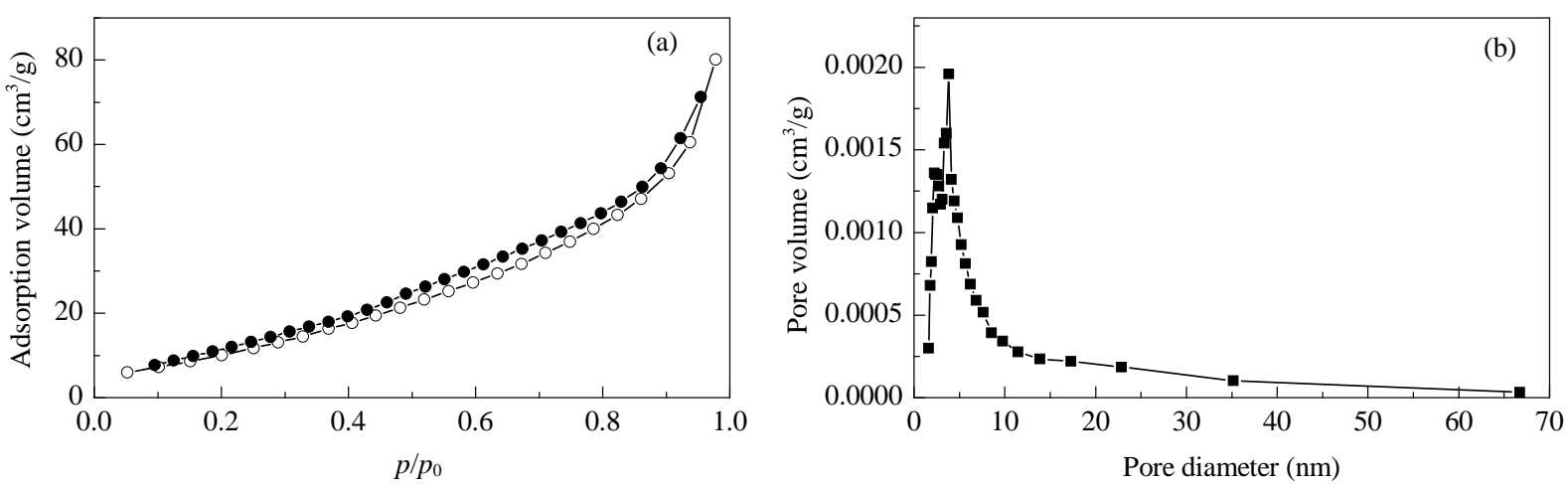

Fig. 5. $\mathrm{N}_{2}$ adsorption-desorption isotherm (a) and pore size distribution (b) of $1.0 \% \mathrm{CdS} / \mathrm{TiO}_{2}$. 


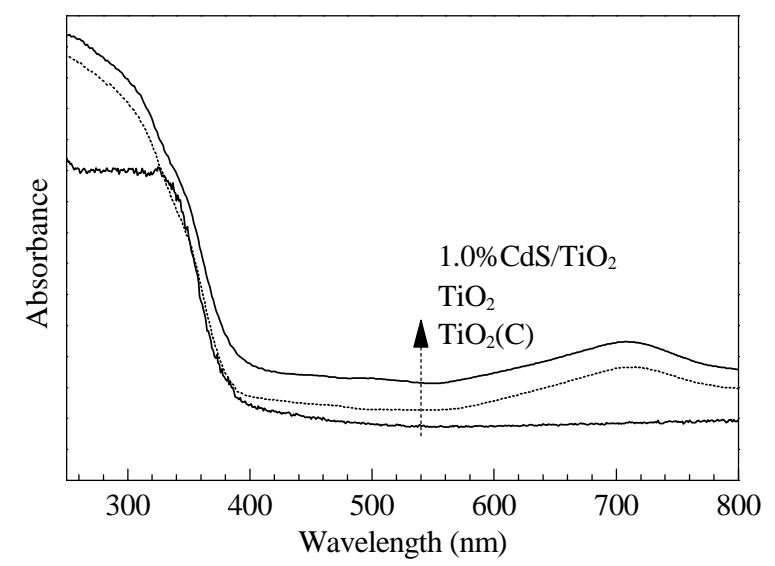

Fig. 6. UV-Vis DRS spectra of $1.0 \% \mathrm{CdS} / \mathrm{TiO}_{2}, \mathrm{TiO}_{2}$, and $\mathrm{TiO}_{2}(\mathrm{C})$ film.

The pore sizes were in the range of 2.0-3.8 $\mathrm{nm}$, implying the existence of a mesoporous structure in the macroporous wall, which would be beneficial for the adsorption of reactants. The $A_{\text {BET }}$ was $43 \mathrm{~m}^{2} / \mathrm{g}$, as calculated by the BET method.

Figure 6 shows the UV-Vis diffuse reflectance (DRS) spectra of the various samples, which revealed that the macroporous structure in the $\mathrm{TiO}_{2}$ film was favorable for light absorption and it gave a higher light harvest than the $\mathrm{TiO}_{2}(\mathrm{C})$ film. This can be attributed to light multiple reflection in the macroporous structure. In addition, the modification with CdS by ion exchange further enhanced the absorption of visible light. The $1.0 \% \mathrm{CdS} / \mathrm{TiO}_{2}$ film showed a lower PL peak intensity than the $\mathrm{TiO}_{2}$ film (see Fig. 7), which indicated a lower recombination probability of the photo-induced charges due to the formation of the $\mathrm{CdS}-\mathrm{TiO}_{2}$ heterojuction. This would benefit the quantum efficiency of the photocatalytic reaction. This can be ascribed to that the photo-generated electrons were transferred from CdS to the $\mathrm{TiO}_{2}$ conduction band under light irradiation so that the electron density in the $\mathrm{TiO}_{2}$ conduction band was increased and this efficiently inhibited the recombination of photo-induced holes and electrons, as shown in Fig. 8.

\subsection{Photocatalyst activity}

The photo-degradation of RhB under visible light irradiation

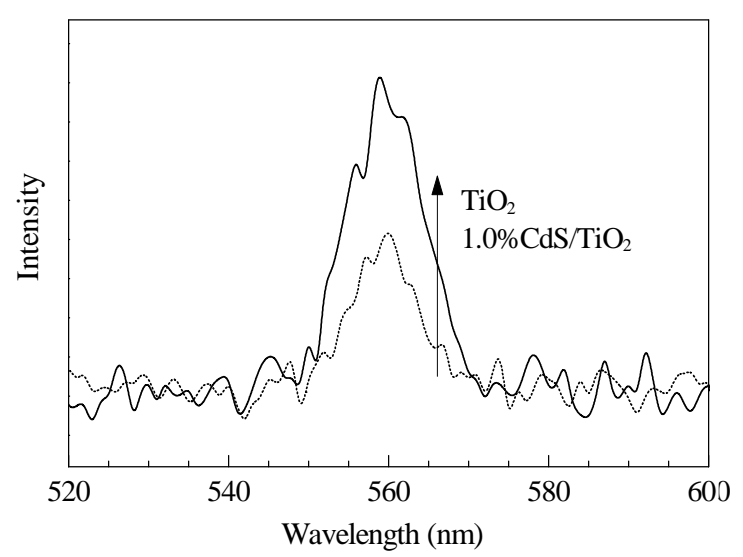

Fig. 7. $\mathrm{PL}$ spectra of $1.0 \% \mathrm{CdS} / \mathrm{TiO}_{2}$ and $\mathrm{TiO}_{2}$ films. The excitation wavelength is $280 \mathrm{~nm}$.

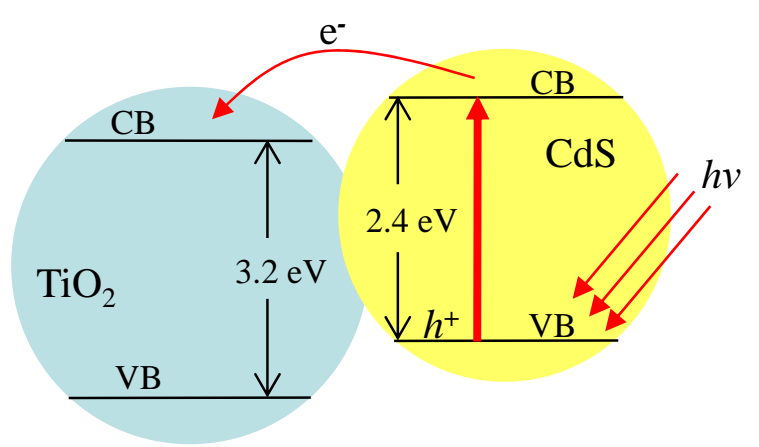

Fig. 8. Illustration of electron transfer between $\mathrm{CdS}$ and $\mathrm{TiO}_{2}$ in the $\mathrm{CdS} / \mathrm{TiO}_{2}$ film.

with the various samples and without a catalyst are presented in Fig. 9. The degradation rate of $\mathrm{RhB}$ without a catalyst was less than $2 \%$ and it can be neglected. Macroporous $\mathrm{TiO}_{2}$ and the $1.0 \% \mathrm{CdS} / \mathrm{TiO}_{2}$ film exhibited obviously increased activity over the $\mathrm{TiO}_{2}(\mathrm{C})$ and $1.0 \% \mathrm{CdS} / \mathrm{TiO}_{2}(\mathrm{C})$ films without template, which was ascribed to the enhancement of light harvest and faster reactant transport in the macropores. Furthermore, the sensitization effect of CdS promoted visible light photoactivity. In comparison to the pure $\mathrm{TiO}_{2}$ film, the $\mathrm{CdS} / \mathrm{TiO}_{2}$ films with different CdS contents showed higher activities. The highest activity was with the $1.0 \% \mathrm{CdS}$ molar ratio with a degradation rate of $>50 \%$ in $100 \mathrm{~min}$. This resulted from improved visible light utilization and lower recombination due to CdS modification, leading to a higher quantum efficiency and photocatalytic activity [17]. In order to avoid the sensitization effect of RhB, the photo-degradation of 4 -CP by the different $\mathrm{CdS} / \mathrm{TiO}_{2}$ films was also investigated under visible light irradiation (Fig. 10). The pure $\mathrm{TiO}_{2}$ film did not degrade 4-CP under visible light. The degradation rates of the CdS-modified samples increased with increasing $\mathrm{CdS}$ concentration and reached the highest rate at the $1.0 \% \mathrm{CdS}$ molar ratio, in agreement with the degradation of RhB. This further confirmed that the improved effect was due to CdS-sensitization of the photocatalyst.

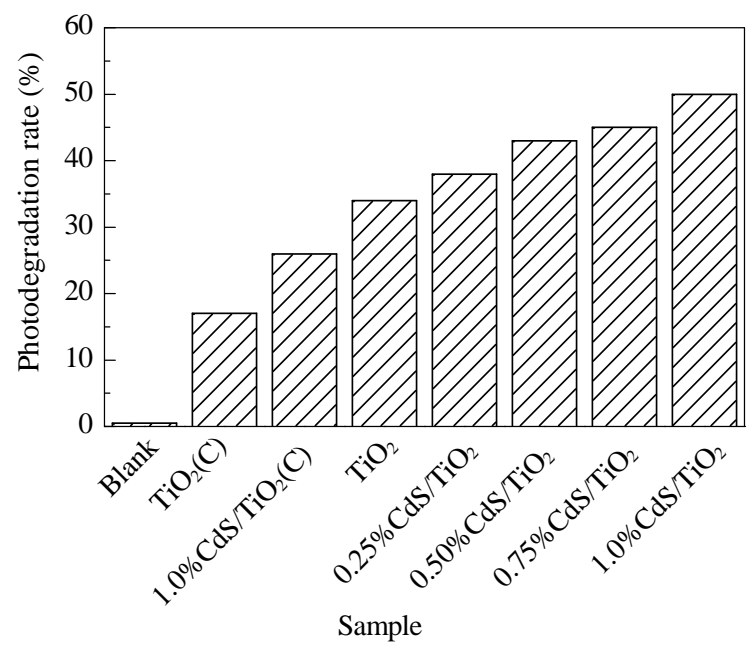

Fig. 9. Photocatalytic activity of different catalyst films for RhB degradation. Reaction conditions: surface area of film $=18.75 \mathrm{~cm}^{2}, 5 \mathrm{ml} \mathrm{RhB}$ solution (10 mg/L), one $500 \mathrm{~W}$ Xe lamp, $\lambda \geq 420 \mathrm{~nm}, 30^{\circ} \mathrm{C}$. 


\title{
Graphical Abstract
}

Chin. J. Catal., 2013, 34: 949-955 doi: 10.1016/S1872-2067(12)60560-9

Preparation and visible light catalytic activity of three-dimensional ordered macroporous $\mathrm{CdS} / \mathrm{TiO}_{2}$ films

CHEN Xiaofang, ZHANG Jia, HUO Yuning*, LI Hexing*

Shanghai Normal University

Three-dimensional ordered macroporous $\mathrm{CdS} / \mathrm{TiO}_{2}$ films prepared by the sol-gel method with a colloidal crystal template and S2- ion exchange exhibited improved visible light photocatalytic activity due to improved light utilization and CdS photosensitization.

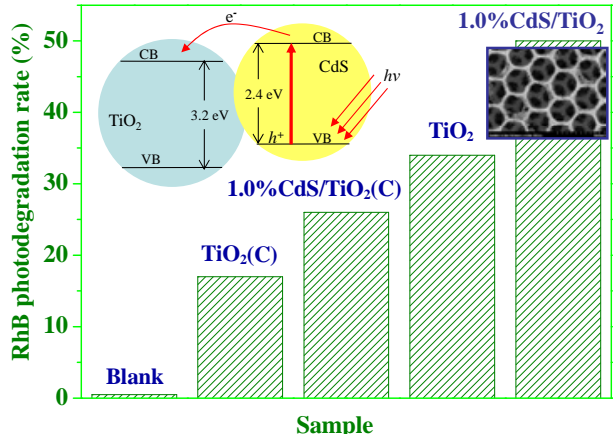

Sample

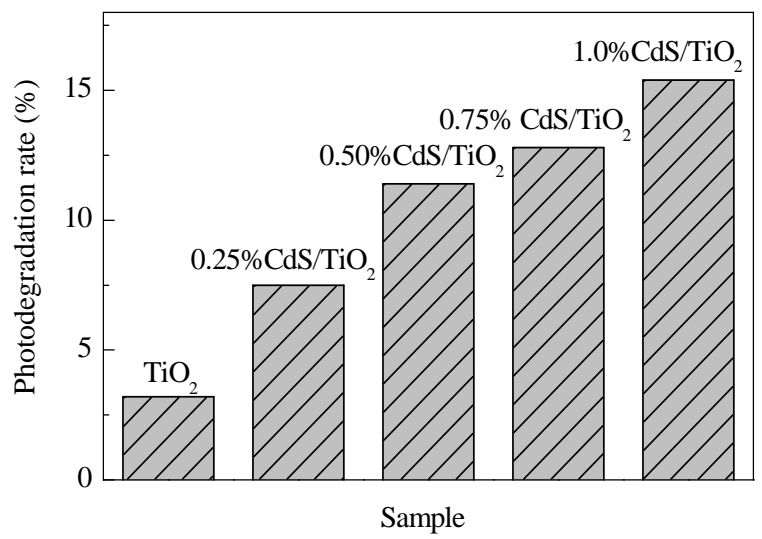

Fig. 10. Photocatalytic activity of different catalyst films for 4-CP degradation. Reaction conditions: surface area of film $=18.75 \mathrm{~cm}^{2}, 5 \mathrm{ml}$ 4-CP solution (15 mg/L), one $500 \mathrm{~W}$ Xe lamp, $\lambda \geq 420 \mathrm{~nm}, 30^{\circ} \mathrm{C}$.

\section{Conclusions}

Three-dimensional ordered macroporous $\mathrm{CdS} / \mathrm{TiO}_{2}$ films were synthesized using the sol gel method with a colloidal crystal template and $\mathrm{S}^{2-}$ ion exchange. CdS was uniformly distributed in the anatase $\mathrm{TiO}_{2}$ macroporous structure. The light utilization was enhanced by light multiple reflection in the ordered macroporous structure. The modification with CdS enabled visible light harvest and improved the separation of photo-induced electrons and holes. The $\mathrm{CdS} / \mathrm{TiO}_{2}$ film with the $1 \%$ $\mathrm{CdS}$ molar ratio showed the highest visible light photocatalytic activity in the aqueous degradation of RhB and 4-CP.

\section{References}

[1] Yi F Y, Chen Sh X, Yuan Ch E. J Hazard Mater, 2008, 157: 79

[2] Ge Q Ch, Wang P, Wan Ch F, Chung T-S. Environ Sci Technol, 2012, 46: 6236

[3] Chen X B, Samuel S M. Chem Rev, 2007, 107: 2891

[4] Hernández-Alonso M D, Fresno F, Suarez S, Coronado J M. Energy Environ Sci, 2009, 2: 1231

[5] Bian Zh F, Zhu J, Wang Sh H, Cao Y, Qian X F, Li H X. J Phys Chem C, 2008, 112: 6258

[6] Shao Y, Ma Y. Sci China Chem, 2012, 55: 1155

[7] Zhu W, Liu X, Liu H Q, Tong D L, Yang J Y, Peng J Y. J Am Chem Soc, 2010, 132: 12619

[8] Kim H, Kim J, Kim W, Choi W. J Phys Chem C, 2011, 115: 9797

[9] Zhou Q, Yuan B L, Xu D X, Fu M L. Chin J Catal (周强, 苑宝玲, 许东 兴, 付明来. 催化学报), 2012, 33: 850

[10] Li G-Sh, Zhang D Q Yu J C. Environ Sci Technol, 2009, 43: 7079

[11] Xu J, Yang B F, Wu M, Fu Zh P, Lü Y, Zhao Y X. J Phys Chem C, 2010, 114: 15251

[12] Rajeswari R, Kanmani S. J Adv Oxid Technol, 2009, 12: 208

[13] Wang J X, Wen Y Q, Feng X J, Song Y L, Jiang L. Macromol Rapid Commun, 2006, 27: 188

[14] Yu J C, Wu L, Lin J, Li P Sh, Li Q. Chem Commun, 2003: 1552

[15] Chen S, Paulose M, Ruan C, Mor G K, Varghese O K, Kouzoudis D, Grimes C A.J Photochem Photobiol A, 2006, 177: 177

[16] Huo Y N, Yang X L, Zhu J, Li H X. Appl Catal B, 2011, 106: 69

[17] Cao F L, Wang J G, Bian Zh F, Zhu J. J Shanghai Normal Univ (Nat $S c i$ ) (曹锋雷, 王金果, 市振锋, 朱建. 上海师范大学学报(自然科学 版)), 2011, 40: 551

\section{三维有序大孔 $\mathrm{CdS} / \mathrm{TiO}_{2}$ 薄膜的制备及其可见光催化性能}

\author{
陈晓芳, 张佳, 霍宇凝*, 李和兴 ${ }^{*}$ \\ 上海师范大学化学系, 上海200234
}

摘要: 采用胶体晶体模板辅助溶胶-凝胶法以及 $\mathrm{S}^{2-}$ 离子交换法合成了三维有序大孔CdS/TiO 2 膜. 结果表明, 该薄膜材料在可见光 催化降解污染水中罗丹明 $\mathrm{B}$ 和对氯苯酚的反应中表现出高活性. 这可归因于修饰剂CdS的光敏化作用实现可见光催化, $\mathrm{CdS}-\mathrm{TiO}_{2}$ 之间形成了异质结, 促进了电子和空穴的分离; 另一方面, 有序大孔结构有利于光的利用以及反应物的扩散和吸附.

关键词: 硫化镉/二氧化钛薄膜; 三维有序大孔结构; 可见光; 光催化 
收稿日期: 2013-01-06. 接受日期: 2013-02-15. 出版日期: 2013-05-20.

*通讯联系人. 电话: (021)64322272; 传真: (021)64322272; 电子信箱: huoyuning@shnu.edu.cn

\#通讯联系人. 电话: (021)64322272; 传真: (021)64322272; 电子信箱: hexing-li@shnu.edu.cn

基金来源：国家自然科学基金(20937003，21261140333，21237003，21207091); 上海市科委项目(11JC1409000, 12230706000); 上 海市教委创新项目(12YZ091).

本文的英文电子版由Elsevier出版社在ScienceDirect上出版(http://www.sciencedirect.com/science/journal/18722067).

\section{1. 前言}

有机污染物是造成全球性污染, 尤其是水污染的主 要因素 ${ }^{[1,2]}$. 利用光催化技术降解有机污染物具有环境 友好、反应条件温和、节能和成本低等优点 ${ }^{[3,4]}$. 虽然目 前常用的 $\mathrm{TiO}_{2}$ 光催化剂表现出性能稳定、无毒、无二次 污染、价格低廉等特点, 但由于其禁带宽度较大, 只能被 紫外光激发, 因而不能有效利用太阳光, 同时量子效率 低 ${ }^{[5,6]}$. 采用不同方法对 $\mathrm{TiO}_{2}$ 进行修饰可有效实现在可 见光下进行光催化反应 ${ }^{[7]}$. 其中, 基于 CdS 的敏化作用 (禁带宽度为 $2.4 \mathrm{eV}$ ) 而使 $\mathrm{CdS} / \mathrm{TiO}_{2}$ 成为广受关注的可见 光催化剂 ${ }^{[8]}$. 目前, 研究较多的是粉末状 $\mathrm{CdS} / \mathrm{TiO}_{2}{ }^{[9,10]}$, 但在液相反应中, 光催化剂粉体与反应体系分离困难.

光催化膜反应器由于无需进行催化剂的分离, 因此 可实现水中有机污染物的连续治理. 但是, 目前仍难以 制备 CdS 分布均匀且 $\mathrm{CdS}-\mathrm{TiO}_{2}$ 结合力强的 $\mathrm{CdS} / \mathrm{TiO}$ 膜; 同时, 大多数膜光催化剂对光的利用率不高, 且存在较 大的传质限制. 研究表明, 三维有序大孔结构有利于提 高材料的比表面积, 促进反应物的传输以及对光的吸收 利用, 因而在环境污染物控制以及太阳能利用等领域备 受关注 ${ }^{[11,12]}$. 本文采用胶体晶体模板辅助溶胶-凝胶法 以及离子交换法制备了三维有序大孔 $\mathrm{CdS} / \mathrm{TiO}_{2}$ 薄膜材 料, 以提高薄膜材料的可见光吸收性能和光催化活性.

\section{2. 实验部分}

\section{1. $\mathrm{CdS} / \mathrm{TiO}_{2}$ 膜的制备}

\subsection{1. 胶粒晶体模板的制备}

采用无乳化剂的乳化聚合法制备胶粒晶体 ${ }^{[13]}$. 取 $21 \mathrm{ml}$ 苯乙烯、 $0.95 \mathrm{ml}$ 丙烯酸及 $1.1 \mathrm{ml}$ 甲基丙烯酸甲酯分 散于 $6.3 \mathrm{mmol}$ 重碳酸铵缓冲溶液 $(0.50 \mathrm{~g}$ 碳酸氢铵溶于 $100 \mathrm{ml}$ 蒸馏水)中, 在 $70{ }^{\circ} \mathrm{C} 反$ 应 $0.5 \mathrm{~h}$, 然后加入 $2.3 \mathrm{mmol}$ 过硫酸铵水溶液, 升温至 $80{ }^{\circ} \mathrm{C}$, 持续搅拌 $10 \mathrm{~h}$, 即获得单 分散的核壳乳胶粒晶体悬浮液, 即聚(苯乙烯-甲基丙烯 酸甲酯-丙烯酸), 简写为P(ST-MMA-AA).

\subsection{2. 胶体晶体薄膜的制备}

使用 $1.00 \mathrm{~mol} / \mathrm{L}$ 的 $\mathrm{NaOH}$ 溶液浸泡载玻片 $2 \mathrm{~h}$, 之后 分别使用丙酮、乙醇和去离子水超声清洗后烘干备用.
配制 $0.250 \%$ 核壳乳胶粒悬浮液于 $50 \mathrm{ml}$ 烧杯中, 超声使 得溶液分散均匀, 沿烧杯壁垂直置入处理好的玻片, 在 $60{ }^{\circ} \mathrm{C}$ 烘箱中放置 $24 \mathrm{~h}$ 后取出. 由于蒸发作用, 核壳乳胶 粒粒子会向载玻片表面迁移, 最终在表面形成薄膜.

\subsection{3. 有序大孔CdS/ $\mathrm{TiO}_{2}$ 薄膜的制备}

采用胶体晶体模板辅助溶胶-凝胶法制备有序大孔 $\mathrm{CdS} / \mathrm{TiO}_{2}$ 薄膜. 于 $20 \mathrm{ml}$ 乙醇中逐滴加入 $1.0 \mathrm{ml}$ 四氯化钛, 搅拌 $5 \mathrm{~min}$ 后加入不同摩尔浓度的硝酸镉, 搅拌至溶解, 之后加入 $3.0 \mathrm{ml}$ 钛酸四丁酯, 搅拌 $2 \mathrm{~h}$ 后即得到硝酸镉含 量不同的 $\mathrm{TiO}_{2}$ 前驱体溶胶. 将带有胶体晶体模板薄膜的 载玻片倾斜 $15^{\circ}$ 放置, 取 $0.10 \mathrm{ml}$ 溶胶滴加在载玻片表面, 前驱体溶胶通过毛细作用渗透到模板空隙内后, 置于室 温中晾干, 并于 $400{ }^{\circ} \mathrm{C}$ 焙烧 $6 \mathrm{~h}$ (升温速率 $2^{\circ} \mathrm{C} / \mathrm{min}$ ). 冷却 后将载玻片置于 $\mathrm{Na}_{2} \mathrm{~S}$ 溶液 $(0.20 \mathrm{~mol} / \mathrm{L})$ 中, 浸渍 $12 \mathrm{~h}$ 以进 行离子交换, 使用去离子水冲洗干净, 烘干后即可得到 样品, 记为 $x \mathrm{CdS} / \mathrm{TiO}_{2}$, 其中 $x$ 为 $\mathrm{Cd} / \mathrm{Ti}$ 摩尔比, 分别为 $0.00 \%, 0.25 \%, 0.50 \%, 0.75 \%$ 和 $1.0 \%$. 继续增加 $\mathrm{Cd} / \mathrm{Ti}$ 摩 尔比则无法得到大孔结构.

作为对比, 在无模板的条件下, 采用以上溶剂凝胶 过程制备得到的薄膜材料分别记为 $\mathrm{TiO}_{2}(\mathrm{C})$ 和 $1.0 \% \mathrm{CdS} / \mathrm{TiO}_{2}(\mathrm{C})$. 未采用 $\mathrm{Na}_{2} \mathrm{~S}$ 进行离子交换的样品记 为 $1.0 \% \mathrm{CdO} / \mathrm{TiO}_{2}$.

\section{2. 催化剂的表征}

采用Rigaku公司Dmax-3C型X射线衍射(XRD)仪进 行薄膜的物相分析, $\mathrm{Cu}$ 辐射源 $(0.154 \mathrm{~nm})$, 扫描速率 $4 \%$ min. 采用日立公司 S- 4800 型扫描电子显微镜(SEM) 以及JEOL TEM 2011型高分辨透射电子显微镜(TEM)测 试样品的形貌. 采用Quantachrome公司NOVA 4000e型 自动物理吸附仪测定样品的 $\mathrm{N}_{2}$ 吸附-脱附曲线, 用BET方 程计算催化剂的比表面积 $\left(A_{\mathrm{BET}}\right)$, 由脱附曲线得到孔径 分布. 在岛津UV-2450型分光光度计上进行紫外-可见 漫反射光谱(UV-Vis DRS)测试, 测试范围200 800 nm, 以高纯 $\mathrm{BaSO}_{4}$ 为标准试剂. 采用Versa Probe PHI 5000 型X射线光电子能谱(XPS)仪对催化剂样品进行测试. 以 $\mathrm{Al}(1486.6 \mathrm{eV})$ 为发射源, 以污染碳的结合能( C 1s = $284.8 \mathrm{eV}$ ) 为基准进行结合能校正。采用 Varain Cary-Eclipse 500型苂光(PL)光谱仪测试样品的苂光光 
谱, $65 \mathrm{~W}$ 氙灯作为激发光源, 扫描速率 $600 \mathrm{~nm} / \mathrm{min}$.

\section{3. 催化剂的评价}

将3片镀有 $\mathrm{CdS} / \mathrm{TiO}_{2}$ 光催化薄膜的载玻片 $(2.5 \mathrm{~cm} \times$ $2.5 \mathrm{~cm}$ ) 置于聚四氟乙烯反应器中, 取 $5.0 \mathrm{ml}$ 罗丹明 $\mathrm{B}$ $(\mathrm{RhB})$ 溶液(初始浓度 $10 \mathrm{mg} / \mathrm{L}$ ) 或 $5.0 \mathrm{ml}$ 对氯苯酚(4-CP) 溶液(初始浓度 $15 \mathrm{mg} / \mathrm{L}$ )为目标降解物进行光催化反应. 以一只 $500 \mathrm{~W}$ 氙灯为光源, 使用滤波片去除 $\lambda<420 \mathrm{~nm}$ 的 光, 反应温度为 $30^{\circ} \mathrm{C}$. 光催化活性测试前, 吸附 $0.5 \mathrm{~h}$ 以 达到吸附平衡. 开灯反应 $100 \mathrm{~min}$ 后, 取出反应溶液, 使 用 UV-Vis 分光光度计分别在 $\lambda=554$ 和 $224 \mathrm{~nm}$ 处测定 $\mathrm{RhB}$ 和4-CP溶液浓度, 并计算各自的降解率.

\section{3. 结果与讨论}

\section{1. 催化剂的结构}

图1为有序大孔 $1.0 \% \mathrm{CdO} / \mathrm{TiO}_{2}$ 及 $1.0 \% \mathrm{CdS} / \mathrm{TiO}_{2}$ 薄膜 材料的FESEM照片. 可以看出, $1.0 \% \mathrm{CdO} / \mathrm{TiO}_{2}$ 薄膜为大 范围的有序大孔结构, 离子交换处理后得到的 $1.0 \% \mathrm{CdS} / \mathrm{TiO}_{2}$ 薄膜仍很好地保持了三维有序大孔结构, 孔径约为 $300 \mathrm{~nm}$, 孔壁厚度约为 $40 \mathrm{~nm}$, 说明胶体晶体模 板辅助溶胶-凝胶法结合离子交换法可成功制得有序大 孔CdS/ $/ \mathrm{TiO}_{2}$ 薄膜材料. 图2为它们的XRD谱. 由图可见, $1.0 \% \mathrm{CdS} / \mathrm{TiO}_{2}$ 大孔薄膜与 $\mathrm{TiO}_{2}$ 大孔薄膜的衍射峰位置 一致, 可归属为锐钛矿相 $\mathrm{TiO}_{2}$ (JCPDS 21-1272). 由于 CdS的分散度高、含量低, 故无明显的CdS衍射峰.

图3为 $1.0 \% \mathrm{CdS} / \mathrm{TiO}_{2}$ 薄膜样品的HRTEM照片. 可以 观察到两种不同的晶面间距, 即 $\mathrm{TiO}_{2}(101)$ 面(0.35 nm) 和 $\mathrm{CdS}(002)$ 面(0.34 nm), 与文献 ${ }^{[14]}$ 一致, 进一步证实CdS均 匀分布于 $\mathrm{TiO}_{2}$ 有序大孔结构中且结晶度较高. 从插图中 的TEM照片亦可明显看出规整排布的大孔结构, 与之前 的结果一致.

图4为 $1.0 \% \mathrm{CdS} / \mathrm{TiO}_{2}$ 薄膜样品的XPS谱. 可以看出, $\mathrm{Ti} 2 p, \mathrm{O} 1 \mathrm{~s}$ 和 Cd 3d 谱峰位置与纯相 $\mathrm{TiO}_{2}$ 及 $\mathrm{CdS}$ 的一 致 ${ }^{[15,16]}$, 进一步证明该复合材料是以 CdS 复合 $\mathrm{TiO}_{2}$ 的形 式存在. 这是由于 $\mathrm{CdS}$ 中 $\mathrm{Cd}^{2+}$ 半径 $(97 \mathrm{pm})$ 远大于 $\mathrm{Ti}^{4+}(61$ $\mathrm{pm})$, 因而CdS无法进入 $\mathrm{TiO}_{2}$ 的晶格形成离子掺杂.

图 5 为 $1.0 \% \mathrm{CdS} / \mathrm{TiO}_{2}$ 薄膜的 $\mathrm{N}_{2}$ 吸附-脱附等温线及 孔径分布图. 由图可见, 样品的孔径主要集中在2.0 3.8 $\mathrm{nm}$, 说明薄膜材料的大孔孔壁中含有介孔, 因而有利于 反应物的吸附; 测得其比表面积为 $43 \mathrm{~m}^{2} / \mathrm{g}$.

图6为不同薄膜材料的UV-Vis DRS 谱. 由图可知, $\mathrm{TiO}_{2}$ 薄膜的大孔结构有助于提高催化剂对光的吸收, 因
而较 $\mathrm{TiO}_{2}(\mathrm{C})$ 薄膜表现出更高的光吸收强度. 这主要是 由于规整的大孔结构可产生光在其中的多次反射效应 所致. 同时, 对 $\mathrm{TiO}_{2}$ 薄膜通过离子交换处理进行 $\mathrm{CdS}$ 修 饰后可有效增强薄膜的可见光吸收. 图 7 为 $1.0 \% \mathrm{CdS} / \mathrm{TiO}_{2}$ 与 $\mathrm{TiO}_{2}$ 薄膜样品的 PL谱. 由图可见, $1.0 \% \mathrm{CdS} / \mathrm{TiO}_{2}$ 薄膜的发射峰强度低于 $\mathrm{TiO}_{2}$ 薄膜, 表明 $1.0 \% \mathrm{CdS} / \mathrm{TiO}_{2}$ 薄膜由于形成了 $\mathrm{CdS}-\mathrm{TiO}_{2}$ 异质结, 复合材 料中光生载流子的复合效率更低, 因而有利于提高光催 化过程的量子效率. 这可归因于受光激发后光生电子由 $\mathrm{CdS}$ 传输至 $\mathrm{TiO}_{2}$ 导带, 增加了 $\mathrm{TiO}_{2}$ 导带上的电子密度, 因 而有效抑制了光生空穴和电子的复合, 如图8所示.

\section{2. 催化剂的光催化活性}

图9为不同薄膜样品及无催化剂时在可见光下降解 $\mathrm{RhB}$ 的性能. 由图可见, 无催化剂作用时, RhB的光降解 率低于 $2 \%$, 可以忽略不计; 而大孔结构的 $\mathrm{TiO}_{2}$ 薄膜及 $1.0 \% \mathrm{CdS} / \mathrm{TiO}_{2}$ 薄膜的光催化活性明显高于无模板制备 的 $\mathrm{TiO}_{2}(\mathrm{C})$ 薄膜及 $1.0 \% \mathrm{CdS} / \mathrm{TiO}_{2}(\mathrm{C})$ 薄膜. 这可归因于规 整的大孔结构增强了光吸收并有利于反应物的传输. 同 时, $\mathrm{CdS}$ 的修饰进一步增强了可见光活性, 与纯 $\mathrm{TiO}_{2}$ 薄膜 相比, 不同 $\mathrm{CdS}$ 含量的 $\mathrm{CdS} / \mathrm{TiO}_{2}$ 薄膜样品的光催化活性 均有提高, 其中 $1.0 \% \mathrm{CdS} / \mathrm{TiO}_{2}$ 薄膜的活性最佳, 在 100 $\min$ 内 RhB 降解率达到 $50 \%$ 以上. 这是由于CdS修饰后有 效增加了 $\mathrm{TiO}_{2}$ 催化剂对可见光的吸收, 同时降低了光生 空穴与电子的复合效率, 因而有利于提高光催化过程的 量子效率并提高光催化活性 ${ }^{[17]}$.

为了消除 RhB 的敏化作用, 本文还考察了不同 $\mathrm{CdS} / \mathrm{TiO}_{2}$ 薄膜样品在可见光下光催化降解 $4-\mathrm{CP}$ 的性能, 结果示于图10. 可以看出, 可见光下 $\mathrm{TiO}_{2}$ 薄膜样品无明 显活性, 经 CdS 修饰的样品上4-CP降解速率随着 CdS 含 量的增加而增加, 至1.0\%时活性最佳, 与样品光催化降 解RhB的规律一致. 这再次证明了 CdS 修饰对光催化活 性的促进作用.

\section{4. 结论}

采用胶体晶体模板辅助溶胶-凝胶法以及离子交换 法合成的三维有序大孔CdS/ $/ \mathrm{TiO}_{2}$ 薄膜中, $\mathrm{CdS}$ 均匀分布 于锐铁矿相 $\mathrm{TiO}_{2}$ 的有序大孔结构中. 由于光在有序大孔 中的多次反射效应, 增强了光吸收. CdS 的修饰实现了 $\mathrm{TiO}_{2}$ 薄膜对可见光的利用并促进了电子和空穴的分离. 在可见光催化降解水中模拟污染物 RhB 及 4-CP的反应 中, CdS 含量为 $1 \%$ 的 $\mathrm{CdS} / \mathrm{TiO}_{2}$ 薄膜的光催化活性最佳. 